\title{
RANDOM AMPLIFIED POLYMORPHIC DNA ANALYSIS OF EFFECTIVE RHIZOBIUM SP. ASSOCIATED WITH BEANS CULTIVATED IN BRAZILIAN CERRADO SOILS
}

\author{
Isnia Aparecida de Oliveira ${ }^{1}$; Maria José Vasconcellos ${ }^{3}$; Lucy Seldin²; Edilson Paiva ${ }^{3}$; Milton Alexandre Vargas ${ }^{4}$; \\ Nadja Maria Horta de Sá ${ }^{*}$
}

'Departamento de Botânica, Instituto de Ciências Biológicas, Universidade Federal de Minas Gerais, Belo Horizonte, MG, Brasil. ${ }^{2}$ Instituto de Microbiologia, Universidade Federal do Rio de Janeiro, Rio de Janeiro, RJ, Brasil. ${ }^{3}$ EMBRAPA, Centro Nacional de Pesquisa de Milho e Sorgo, Sete Lagoas, MG, Brasil. " EMBRAPA, Centro de Pesquisa Agropecuário do Cerrado, Planaltina, DF, Brasil.

Submitted: August 05, 1998; Returned to authors for corrections: January 11, 2000; Approved: March 22, 2000

\begin{abstract}
Efficient bean nodulating Rhizobium strains, isolated from different Brazilian cerrado soils, were characterized by RAPD. This study showed great genetic heterogeneity among $R$. tropici and $R$. leguminosarum bv. phaseoli strains and allowed the constitution of genetic clusters, besides indicating the most suitable primers for this characterization. The groups of genetically distinct strains can be used in competitiveness studies to select appropriate Rhizobium strains for bean inoculation in cerrado soils.
\end{abstract}

Key words: Rhizobium tropici, Rhizobium leguminosarum bv. phaseoli, bean plants, cerrado soils

\section{INTRODUCTION}

Beans are an important staple crop in the cerrado region of Brazil. In 1990, an area of 801,674 hectares was under cultivation, and the production was 431,628 tons (10). However, the $538 \mathrm{~kg} /$ ha average production is considered low. The majority of the bean production in this region takes place on small farms where the use of fertilizers, especially nitrogen, is low. In this context, biological nitrogen fixation assumes an increasing important role. However, inoculating beans with effective strains of Rhizobium is not always successful due to several factors, including the competition that occurs between the inoculated strains and those already present in the soil which generally have low effectiveness $(6,9)$. Competitiveness studies that have been conducted to select bacterial genotypes have been limited due to problems in identifying strains that nodulate this legume. In those organisms, similar antigenic structures (cross-reactivity) are common as seen through serologic tests or classic identification methods $(11,14)$.

However, the development and increased availability of molecular biology techniques have made it possible to obtain information regarding the genomic organization and diversity of rhizobia populations in different soils $(1,3,7)$. Genomic DNA fingerprinting using random amplification of polymorphic DNA (RAPD) has been found to be useful in differentiating between very closely related bacteria. The RAPD technique is a polymerase chain reaction (PCR) based assay that was developed to detect polymorphisms in genomic DNA $(19,20)$. Besides being simpler and cheaper, this method is as effective as the more labor intensive RFLP for establishing genetic relationships and identifying Rhizobium strains $(3,17)$.

In this study, effective native Rhizobium strains isolated from bean plants cultivated in different cerrado regions of Brazil were characterized using genomic patterns obtained through RAPD with the objective of identifying genetic groupings (clusters) of the strains.

\footnotetext{
* Corresponding author. Mailing address: Universidade Federal de Minas Gerais, Instituto de Ciências Biológicas, Departamento de Botânica, Pampulha, CEP 31270-901, Belo Horizonte, MG, Brasil. FAX: (+5531) 499-2673
} 


\section{MATERIALS AND METHODS}

Culture media, growth conditions and maintenance of Rhizobium strains: The 89 strains of Rhizobium used in this study are listed together with their origin and the chemical characteristics of the soil from which they were obtained (Table 1). These strains were previously phenotypically characterized as Rhizobium tropici and R. leguminosarum bv. phaseoli and selected because of their high level of effectiveness in Leonard jars with their homologue host (9). The strains were grown in liquid manitol medium yeast extract (YM) at $29^{\circ} \mathrm{C}$ and maintained in the same medium containing agar (YMA) at $4^{\circ} \mathrm{C}$ (18).

DNA extraction and RAPD analysis: Bacterial DNA genomic was extracted using the method described in Sá et al. (13). DNA amplification reactions of the strains were conducted in a Perkin-Elmer 9600 thermocycler. The amplification reaction was composed of 40 cycles with each cycle having the following steps: denaturation at $94^{\circ} \mathrm{C}$ for $15 \mathrm{sec}$., annealing at $35^{\circ} \mathrm{C}$ for $30 \mathrm{sec}$. and polymerization at $72^{\circ} \mathrm{C}$ for one min. An additional cycle for extension was conducted at $72^{\circ} \mathrm{C}$ for $7 \mathrm{~min}$. Each reaction mixture contained $25 \mu \mathrm{l}$ composed of the following: $2.5 \mathrm{mM}$ of $\mathrm{MgCl}_{2} 10 \mathrm{mM}$ of Tris $\mathrm{KCl}, 0.01 \mathrm{mM}$ of each DNTP (DATP, DCTP, DGTP, DTTP), 1U of Taq DNA polymerase, $0.4 \mu \mathrm{M}$ of primer, $11 \mu 1$ of $\mathrm{H}_{2} \mathrm{O}$ and $25 \mathrm{ng}$ of DNA. The following 27 primers from the Operon Kit (Operon Technologies Inc.) were tested: OPA-05, OPA-08, OPA-09, OPE-02, OPE-03, OPE04, OPE-05, OPE-06, OPF-04, OPF-17, OPG-07, OPG-14,
OPM-07, OPM-04, OPO-09, OPO-11, OPO-14, OPO-16, OPP06, OPP-08, OPP-17, OPP-18, OPS-17, OPW-04, OPW-10, OPW-15. Amplification products were separated using electrophoresis in $1.2 \%$ agarose gels. The gel was visualized by ethidium bromide staining (ETBR) and then photographed. The ETBR stained bands were considered present (1) or absent (0) and only intense, reproducible bands were considered. This data was used to determine the genetic distance between the strains. Average linkage (UPGMA - unweighted pair group method with averages) dendrograms were generated using the Statistica program (Copy Rhigt STATSOFT Inc. 1993 - UNMN 06/74). Principal component analysis (PCA) was also performed with the specific combined data between more effective strains of the two species studied (9), in relation to the tested random primers, using the option factor analysis. In this method, 3 independent consecutive factors are extracted and each consecutive factor maximizes the variability not captured by the preceding factor.

\section{RESULTS AND DISCUSSION}

Random primer genomic DNA amplification of Rhizobium strains associated with beans produced patterns with high levels of polymorphism. Fingerprints were strain-specific with certain primers as can be seen in Figs. 1 and 2. Data processing generated dendrograms (Figs. 3 and 4) that suggested 6 or more major divisions based on the genetic relationship between the Rhizobium strains of the evaluated species. High degrees of

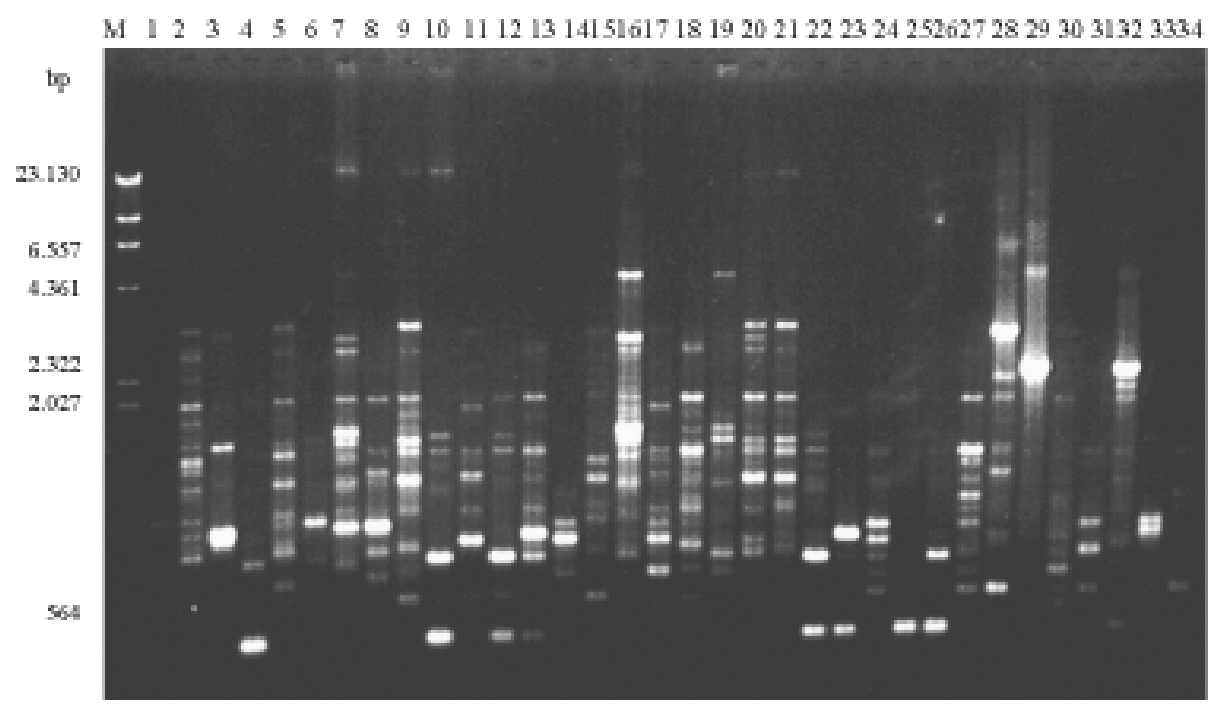

Figure 1. Example of banding patterns obtained from 34 strains of $R$. tropici from Brasilia using primer OPF-04: (M) Kb ladder, (1)CPACH37, (2)CPACH38, (3)CPACH50, (4)CPACH2, (5)CPACH52, (6)CPACH51, (7)CPACH41, (8)CPACH23, (9)CPACH53, (10)CPACH6, (11)CPACH56, (12)CPACH22, (13)CPACH14, (14)CPACH38, (15)CPACH20, (16)CPACH35, (17)CPACH13, (18)CPACH45, (19)CPACH42, (20)CPACH39, (21)CPACH9, (22)CPACH14, (23)CPACH32, (24)CPACH48, (25)CPACH3, (26)FJ1.2, (27)FJ1.22, (28)FJ2.1, (29)FJ2.2, (30)FJ2.4, (31)FJ2.12, (32)FJ2.15, (33)FJ2.21, (34)FJ2.22. 


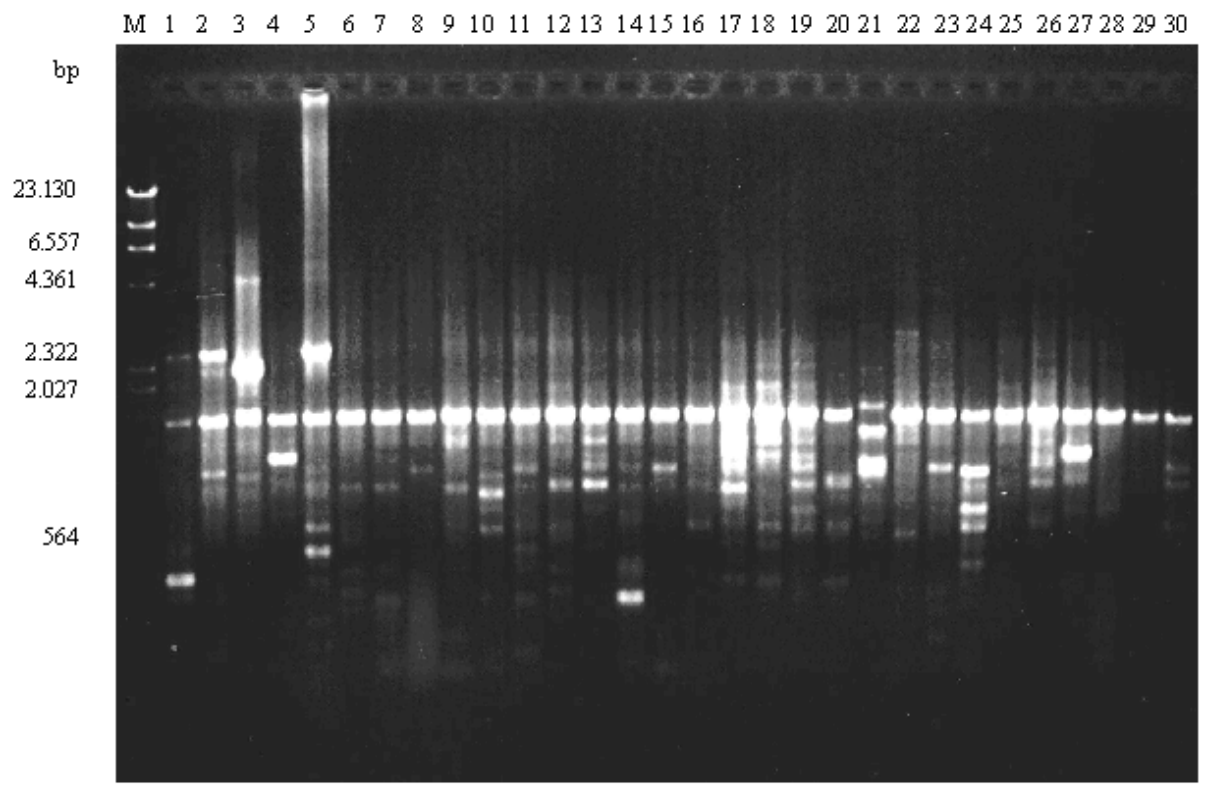

Figure 2. Example of banding patterns obtained from 10 strains of R. tropici (lines 1 to 6 and 18 to 21 ) and 14 R. leguminosarum bv. phaseoli (lines 7 to 17 and 22 to 30) from S. Lagoas cerrado soil using primer OPF-02: (M) Kb ladder, (1)SLA1.2, (2)SLA1.5, (3)SLA1.6, (4)SLA2.2, (5)SLA2.3, (6)SLA3.2, (7)SLA1.1, (8)SLA1.4, (9)SLA3.13, (10)SLBR2.1, (11)SLBR3.12, (12)SLBR3.13, (13)SLB3.3, (14)SLB3.12, (15)SLB3.13, (16)SLB7.15, (17)SLB10.6, (18)SLP2.13, (19)SLP3.3, (20)SLP4.9, (21)SLP5.9, (22)SLP1.3, (23)SLP1.6, (24)SLP2.2, (25)SLP2.10, (26)SLP4.4, (27)SLP4.7, (28)SLP5.8, (29)SLP19.7, (30)SLP24.1.

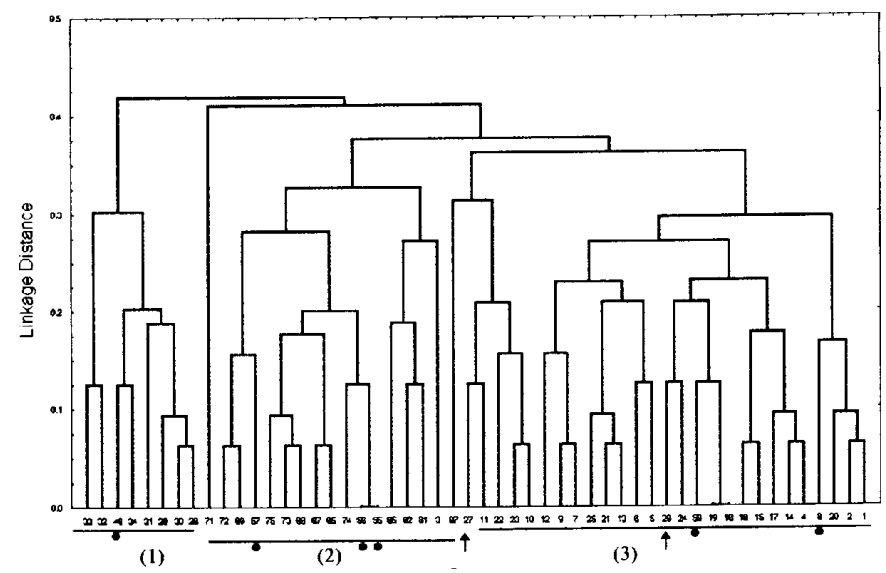

Figure 3. Dendrograms showing genomic relationship between 52 strains of $R$. tropici isolated from cerrado soil as determined by RAPD analysis with 13 different arbitrary primers. (1 and $\uparrow$ ) - Brasilia cerrado soil B, (2) - Sete Lagoas cerrado soil (A, B and C), (3) - Brasilia cerrado soil A, • commercial strains from different origins.

variation were observed in the $R$. tropici (6-42\%) (Fig. 3) as well as in the R. leguminosarum bv. phaseoli strains (5-40\%) (Fig. 4). The constituted groups formed preferentially with strains from the same location (Table 1), indicating the selection of genetically related sub-populations in relation to the soil characteristics of each sample site. Also within each site,

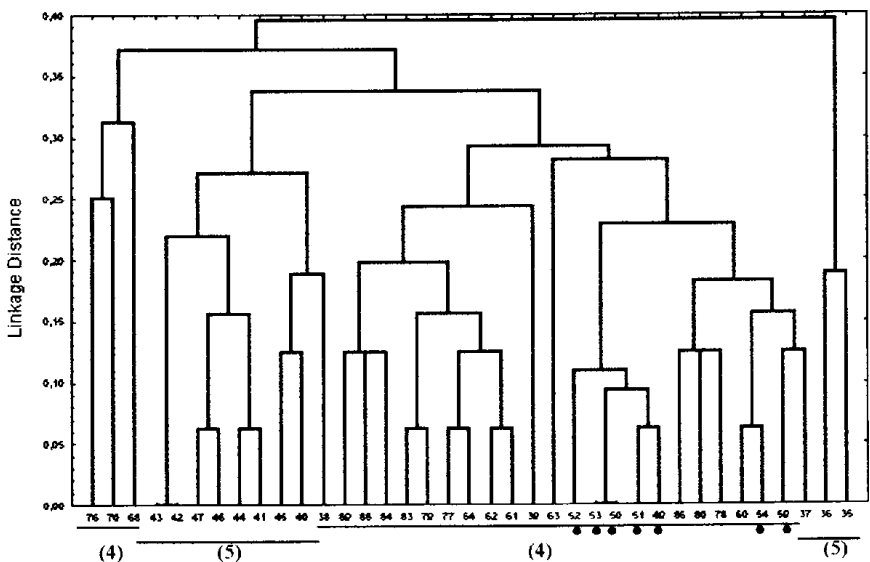

Figure 4. Dendrograms showing genomic relationship between 37 strains of $R$. leguminosarum bv. phaseoli isolated from cerrado soil as determined by RAPD analysis with 13 different arbitrary primers. (4) - Sete Lagoas cerrado soil (A, B and C), (5) - Janauba cerrado soil, • - commercial strains from different origins.

specially Brasilia and Janaúba, high levels of genetic variation were observed. Using the random primer OPF-04, as shown in Fig. 1, DNA amplification of $R$. tropici strains from Brasilia had intensely polymorphic patterns even though the strains had common bands. A dendrogram generated (data not shown) from the results showed genetic variation levels of 6 to $44 \%$ between 
Table 1. Identification, origin of 52 effective strains of $R$. tropici and 37 R. leguminosarum bv. phaseoli and the chemical soil analysis of the isolation sites.

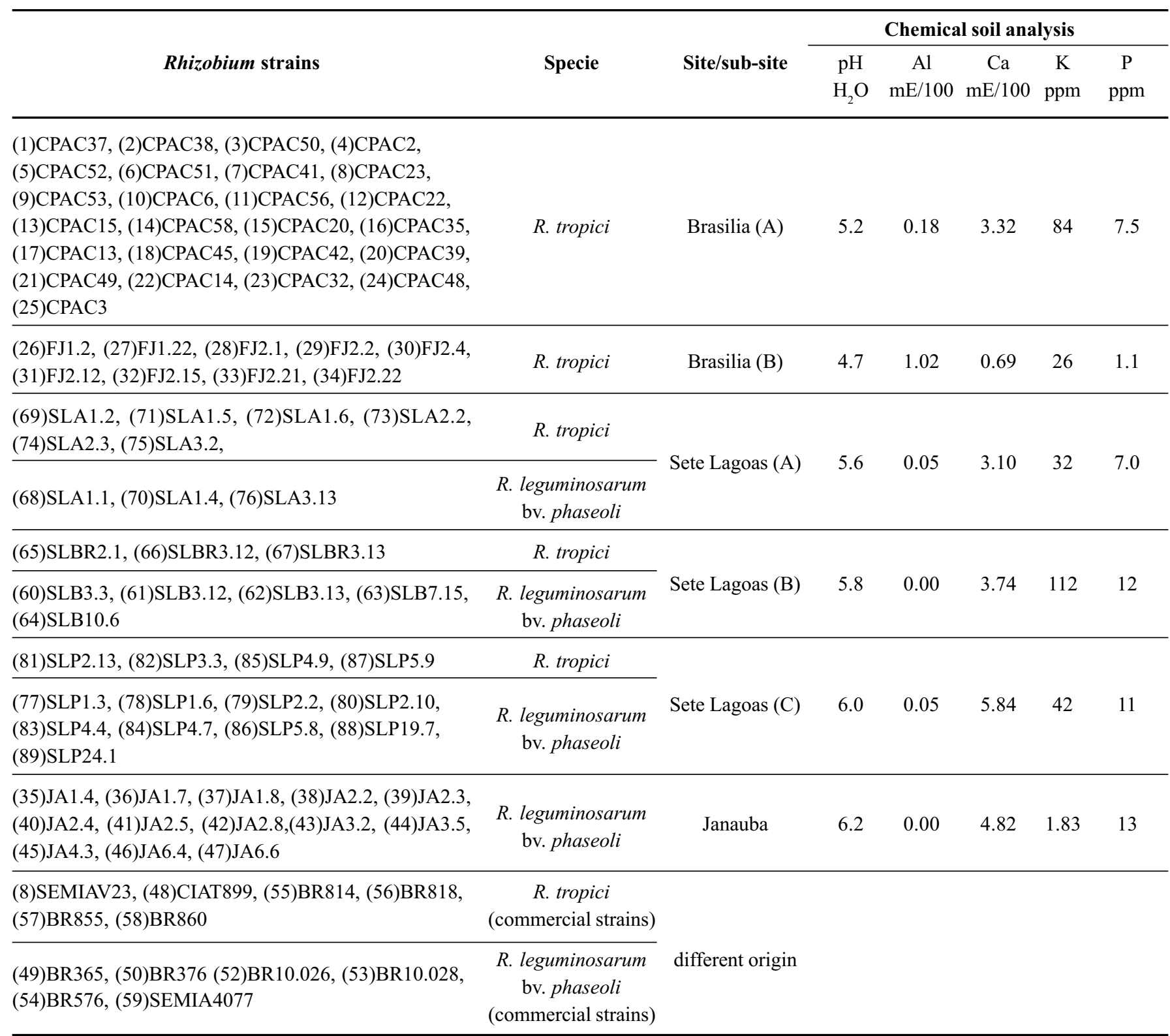

the strains. It was possible to detect at least 4 clusters among the analyzed strains from Brasilia and in sub-sites within the region the genetic variation levels were from $9-40 \%$ (subsite A) and $7-52 \%$ (subsite B). DNA amplification profiles of $R$. leguminosarum bv. phaseoli strains from Janaúba showed that in addition to common bands, these strains had bands that allowed for the differentiation of individual strains. The dendrogram resulting from the use of different primers indicated at least 4 distinct clusters and genetic variation of 6-46\%. Using
OPA-02 primer, $R$. tropici (Fig. 2; lines 1-6 and 18-21) and $R$. leguminosarum bv. phaseoli strains (Fig. 2; lines 7-17 and 2230) from Sete Lagoas produced patterns with high polymorphism, reflected in a dendrogram which showed genetic variation of $6-37 \%$. In samples from the Sete Lagoas region, clusters formed initially by subsite and within them, by Rhizobium species. Subsites of this region had similar levels of genetic variation: subsite A 9.5-46.5\%; subsite B 16-48\%; subsite C $4.5-40 \%$. 
a) R. tropici

- Brasília

S. Lagoas

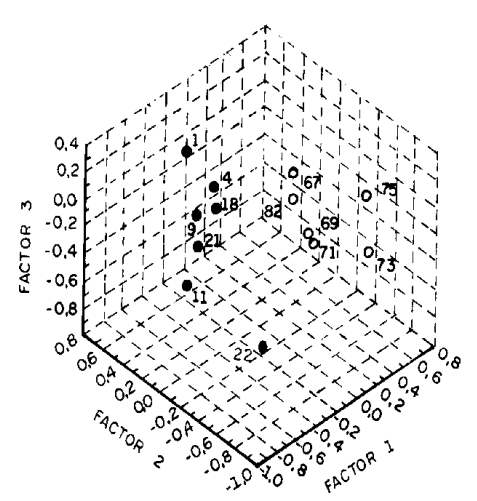

b) R. leguminosarum bv. phaseoli - Janaúba : S. Lagoas

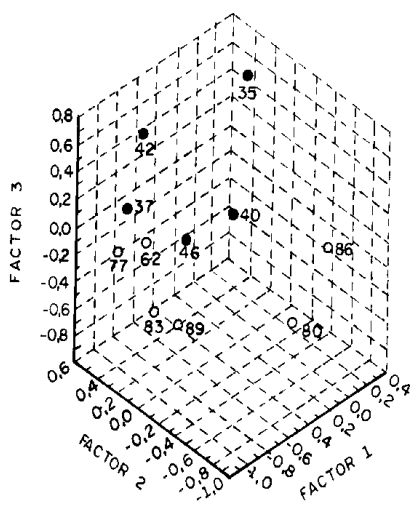

Figure 5. Groups determined using Principal Component Analysis on the specific combing data between the most effective $R$. tropici strains (a) and $R$. leguminosarum bv. phaseoli strains (b) in relation to 13 random primers.

Based on the PCA diagrams (Figs. 5a and b), 2 groups can be distinguished among the most effective strains according to origin of the two species studied ( $R$. tropici and $R$. leguminosarum bv. phaseoli), which confirms the trend observed in the dendrogram analysis. PCA also verified that the $R$. leguminosarum bv. phaseoli strains had more variation among themselves than the $R$. tropici did, probably due to the former's higher genetic plasticity $(12,13)$. In addition, this analysis identified adequate primers for strain identification.

Result of the present study confirm the high degree of genetic diversity found using a variety of methods in bean nodulating Rhizobium strains from Mexican (8) and Brazilian soils $(6,13)$. In general, strains within the Rhizobium genus are fast growing, such as there studied here that nodulate beans. They appear to be more taxonomically diverse and ecologically adaptable than the slower growing strains from other genera like Bradyrhizobium and Azorhizobium These differences probable occur because in the slow growing strains the genetic information, in general, is contained in the chromossomal DNA, while in fast growing strains many genes, including those related to biological nitrogen fixation are located on plasmids which confers dynamic qualities to the genome $(5,12)$. These characteristics favor recombination between genotypes of the Rhizobium population present in soils (14). Even though new bean nodulating Rhizobium species have been defined recently $(4,15)$, additional species should be defined to reflect on the taxonomic level, the large diversity of these bacteria. For now, this study established groups of genetically distinct strains that can be used in competitiveness studies to select appropriate strains for inoculation in cerrado region bean plants.

\section{ACKNOWLEDGMENTS}

The authors thank laboratory technicians Miguel Reis and Renato Simões for their collaboration. This work was supported by $\mathrm{CNPq}$ and FAPEMIG.

\section{RESUMO}

Caracterização, via RAPD, de estirpes efetivas de Rhizobium sp associadas ao feijoeiro cultivado em solos de cerrado no Brasil

Estirpes de Rhizobium eficientes na nodulação do feijoeiro, isoladas de diferentes solos da região do cultivo dessa leguminosa nos cerrados brasileiros, foram caracterizadas via RAPD. Esse estudo mostrou grande heterogeneidade genética entre as estirpes de $R$. tropici e $R$. leguminosarum bv. phaseoli testadas e permitiu a definição de grupos genéticos, além de indicar os "primers" mais adequados para essa caracterização. Os grupos de estirpes geneticamente distintas podem ser usados em estudos de competitividade, importantes para obtenção de resultados positivos na inoculação dessa leguminosa em solos de cerrado.

Palavras-chave: Rhizobium tropici, Rhizobium leguminosarum bv. phaseoli, feijoeiro, solos de cerrado

\section{REFERENCES}

1. Amarger, N.; Bours, M.; Revoy, F.; Allard, M. R.; Laguerre, G. Rhizobium tropici nodulates field - grown Phaseolis vulgaris in France. Plant Soil 161:147-156, 1994.

2. Kattah, L. S.; Pinto, P. P.; Sá, N. M. H. Caracterização de estirpes de Rhizobium nativas isoladas de áreas de cultivo do feijoeiro em solos de cerrado. In: HUNGRIA ET AL, eds. Microbiologia do solo: desafios para o século XXI. Londrina: IAPAR/EMBRAPA - CNPSO, 1995.

3. Laguerre, G.; Mavingui, P. Allard, M.; Charnay, M.; Louvrier, P.; Mazurier, S.; Rigottier, L.; Amarger, N. Typing of Rhizobia by PCR DNA Finger printing and PCR - Restriction Fragment Length Polymorphism Analysis of Chromosomal and Symbiotic Gene Regions: Application to Rhizobium leguminosarum and its different biovars. Appl. Environ. Microbiol. 62: 2029-2036, 1996.

4. Martinez-Romero, E.; Segovia, E.; Mercante, F. M.; Franco, A. A.; Graham, P. H.; Pardo, , M. A. Rhizobium tropici, a novel species nodulating Phaseolus vulgaris L. beans and Leucaena sp. trees. International J. Syst. Bacteriol. 41:417-426, 1991.

5. Martinez - Romero, E. Recent developments in Rhizobium taxonomy. Plant soil. 161:11-20, 1994.

6. Mercante, F. M. Uso de Leucaena leucocephala na obtenção de Rhizobium tolerante a temperatura elevada para inoculação do feijoeiro. UFRRJ Itaguaí 149p. (tese de mestrado), 1993.

7. Nour, S. M.; Fernadez, M. P.; Normand, P.; Cleyetmarel, J. C. Rhizobium ciceri sp. nov., consisting of strains that nodulate chickpeas (cicer arietinum L.). International J. Syst. Bacteriol. 44:511-522, 1994.

8. Pinero, D.; Martinez, E.; Selander, R. K. Genetic diversity and relationships among isolates of Rhizobium leguminosarum bv. phaseoli. Appl. Environ. Microbiol. 54:2825-2832, 1988. 
9. Pinto, P. P.; Kattah, L. S.; Sá, N. M. H. Termotolerancia e eficiência em fixar $\mathrm{N}_{2}$, de estirpes de Rhizobium nativas, isoladas de áreas de cultivo do feijoeiro nos cerrados. XXV Congresso Brasileiro de Ciencia do Solo vol. I, 509 - 510. Viçosa, Brasil, 1995.

10. Pereira, G.; Moreira, L.; Messias, M. O comportamento agropecuário na região nuclear dos cerrados. Planaltina: EMBRAPA - CPAC, 3p. (EMBRAPA - CPAC/PNP). Avaliação dos recursos naturais e sócioeconômicos dos cerrados. Projeto 026.9/801/1. Form. 1.3/1992, 1992.

11. Pereira, J. C.; Vidor, C.; Lovato, P. E.; Penteado, A. Symbiosis among field beans and Rhizobium leguminosarum bv. phaseoli strains sensitive and resistant to antibiotics. Pesqui. Agropecu. Bras. 26:1097-1105, 1991.

12. Romero, P.; Brom, S.; martinez-Salazar, J.; Girard, M. L.; Palacios, R.; Davila, G. Amplification and deletion of a nod - nif region in the symbiotic plasmid of Rhizobium phaseoli. J. Bacteriol. 173:2435-2441, 1991.

13. Sá, N. M. H.; Scotti, M. R. M. M. L.; Paiva, E.; Franco, A. A.; Dobereiner J. Selection and characterization of Rhizobium spp. Strains stable and capable in fixing nitrogen in bean (Phaseolus vulgaris L.). Rev. Microbiol. 24:38-48, 1993.
14. Schmidt, E L.; Bankole, R. O. \& Bohlool, B. B. Fluorescent - antibody approach to study of Rhizobia in soil. J. Bacteriol. 95:1987-1992, 1968.

15. Schofield, P.R.; Gibson, A.H.; Duman, W.F.; Watson, J.M. Evidence for genetic exchange and recombination of Rhizobium symbiotic plasmids in a soil population App. Environ. Microbiol. 53:2842-2947, 1991.

16. Segovia, L.; Young, J. P. W.; Martinez-Romero, E. Reclassification of American Rhizobium leguminosarum biovar phaseoli type I strains as Rhizobium etli sp. nov. International J. Syst. Bacteriol. 43:374-377, 1993.

17. Selenska-Pobell, S.; Euguenieva-Hackenberg, E.; Radeva, G.; Squartini, A. Characterization of Rhizobium "hedysari" by RFLP analysis of PCR amplified rDNA and by genomic PCR fingerprinting. J. Appl. Bacteriol. 80:517-528, 1996

18. Vincent, J. M. A manual for the practical study of root - nodule bacteria 164p. Oxford: Blackwell Science, 1970.

19. Welsh, J.; McClelland, M. Fingerprinting genomes using PCR with arbitrary primers. Nucleic Acids Res. 18:7213-7218, 1990.

20. Williams, J. G. K.; Kubelik, A. R.; Livak, K. J.; Raifalski, A.; Tingey, S. V. DNA polymorphisms amplified by arbitrary primers are usefull as genetic markers. Nucleic Acids Res. 18:6531-6535, 1990. 